\begin{tabular}{|c|c|c|c|}
\hline \multirow{2}{*}{ 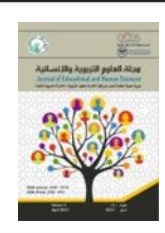 } & \multicolumn{2}{|c|}{$\begin{array}{c}\text { هجلة العلور التربوية والإنسانية } \\
\text { Journal of Educational and Human Sciences } \\
\text { www.jeahs.com }\end{array}$} & \\
\hline & Volume (9) December 2021 & العدد (9) ديسمبر 2021 & \\
\hline
\end{tabular}

\title{
Examining the Predictors of Marital Conflict in Iraq: Social, Economic, or Psychological Factors
}

\author{
Assist. Lect. Abbas Adnan Kamel \\ University of Warith Al-Anbiyaa \\ Iraq \\ Email: abbas.ad@uowa.edu.iq
}

\begin{abstract}
Marriage, like any other human relationship, is not without conflict. Sometimes marital conflicts can be the prelude to divorce. Therefore, finding predictors of marital conflict is very important. In the present study, demographic characteristics and psychological variables such as emotion regulation were examined as predictors of marital conflict. In this study, we also sought the importance of each of these variables. The method of this research was descriptive and correlational and its sample included 112 couples living in Iraq who were selected by snowball sampling . People answered questions online. The results of stepwise regression showed that in wives Lent of marriage, Religious Attendance in husbands, Cognitive reappraisal, Marital Equity, Children Under 18 in Home are predictors of marital conflict. And in men Expression suppression, Gender Role Attitudes, Religious Affiliation in wives, Children Under 18 in Home are the main predictors of marital conflict. This finding shows that demographic and psychological variables are important in both groups. However, in husbands, the psychological variable suppression of expression plays the largest role in predicting marital conflict.
\end{abstract}

Keywords: Marital Conflict, Iraq, Social, Economic, Psychological Factors. 


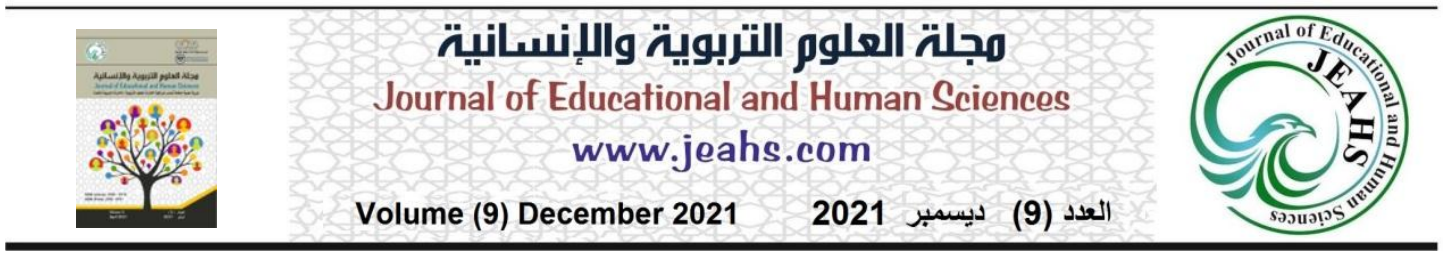

\section{Introduction}

Marriage is the most important foundation in forming a family and is a turning point in the life cycle and an essential aspect of any person's life that commits two people to each other as spouses. Marriage significantly affects a person's life performance including social, emotional, cultural and economic aspects(Sheehan, 2019). Since marriage is a long-term commitment between a man and a woman, it is essential that both parties are satisfied and happy with their married life(Isiozor, Kunutsor, Laukkanen, Kauhanen, \& Laukkanen, 2019). Because of the nature of the relationship between the spouses and the unique personality of each couple, one cannot or does not want to see things exactly as the other person sees them. Therefore, there is a possibility of conflicting views and demands(Samuel \& Alene, 2021). As a result of such a situation, spouses feel anger, frustration, and dissatisfaction with each other, and conflicts occur, so given the nature of the couple's relationship, it is natural for differences and conflicts to arise in the marital relationship(John, 2017). The concept of conflict refers to the lack of disagreement between spouses and means that the person sees a mismatch between their goals, expectations and personal needs or desires of the other partner. Conflict means that a person finds inconsistencies between his or her goals, expectations, and personal desires or those of the other party(Mourtada, Schlecht, \& DeJong, 2017).Conflict theories assert that disagreements and discord are inevitable in close relationships(White, Martin, \& Adamsons, 2018). Social and economic factors play a role in increasing marital conflict. Previous authors have mentioned these factors(Aughinbaugh, Robles, \& Sun, 2013). Family work conflict(Karakose, Yirci, \& Papadakis, 2021), marriage age(Marphatia, Ambale, \& Reid, 2017), traditional and modern society, economic and educational differences have been considered as predictors of marital conflicts. If we consider social and economic factors as stressors, we can conclude that how to manage stress and negative emotions play a significant role in creating marital conflicts caused by these economic and social factors. Previous research has addressed the moderating role of emotion regulation in people's health and marital conflicts(Frye-Cox, Ganong, Jensen, \& Coleman, 2021).

More than twenty years, psychologists have examined various psychological mechanisms that may explain the marital conflicts (Butler \& Sbarra, 2013; Robles et al., 2014). One line of scholarship has explored emotion regulation strategies (J.J. Gross \& Munoz, 1995). Emotion regulation is defined as the ways in which "individuals influence the emotions they have, when they have them, and how they experience and express these emotions" (Gross, 1998, p. 275). Because emotions are closely tied to conflicts and socioeconomic situation, so emotion regulation was considered as a moderating factor in the relationship between marital conflict and socioeconomic status. Because conflict is inevitable in any close relationship, understanding how couples effectively manage conflicts may help practitioners and couples themselves to build skills aimed at lowering the effects of discord on physiological reactions. 


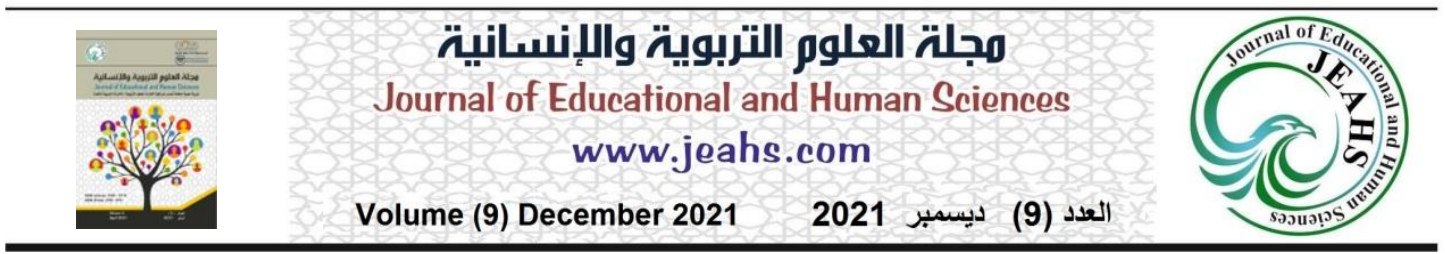

Therefore, in this study we examine predictors of marital conflict among husbands and wives of Iraq. Past research has shown that spouses are more likely to use expressive suppression and cognitive reappraisal(Visher \& Visher, 1997) According to (Gross, 1998) process model of emotion regulation, those occurs throughout emotion-generating interactions, with two widely used emotion regulation strategies, cognitive reappraisal and expression suppression. Cognitive reappraisal occurs when a person changes the emotional impact of a situation in a positive way, this is done by re-framing that situation. (Troy, Shallcross, \& Mauss, 2013). Recent research has shown that cognitive reappraisal is associated with health and is a psychological protective factor, especially for people who experience high levels of stress. (Morris, Schueller, \& Picard, 2015). Expressive suppression is the removal, concealment, or suppression of an emotional response that typically occurs in response to an event. Expressive suppression, while seemingly reducing the occurrence of emotions, nevertheless increases the experience of emotions, especially negative and intolerable emotion. (Webb, Miles, \& Sheeran, 2012) Because dialogue is one of the most important components of married life, verbal repression leads to the concealment of emotions and thus reduces dialogue between husband and wife. (Frye, Ganong, Jensen, \& Coleman, 2020) As a result, marital issues remain unresolved and marital conflicts increase.

This strategy of canceling conflicts and problems as if they do not exist, sometimes called pseudo mutuality (Visher \& Visher, 1997). There is some evidence that emotion regulation strategies are associated with resolving marital problems (Frye et al., 2020) Cognitive reappraisal may strengthen marital relationships by strengthening individuals' perceptions of their partner and by reduction of marital conflict. (BenNaim, Hirschberger, Ein-Dor, \& Mikulincer, 2013) In contrast, expressive suppression may reduce marital quality and satisfaction(Klein, Renshaw, \& Curby, 2016). Because conflict is an integral part of human communication, and because emotion regulation is known as one of the predictors of marital conflict, and on the other hand, social and economic issues such as unemployment, age gap, etc. can be conflict. The aim of this study is to determine the contribution of emotion regulation and economic and social issues in predicting marital conflicts.

\section{Methods}

Snowball sampling was used to select of couples in this study. Initial outreach efforts were made through online advertisements (e.g., WhatsApp and Telegram) and wordof-mouth. Online advertising includes an Internet link to Google Drive that contains questionnaires. Before entering the main questionnaires, the inclusion criteria were asked and if the inclusion criteria were approved, the main question file would be available to the couple. These inclusion criteria include a) both couples are willing to participate in the research and b) both have access to the Internet. Each couple completed one screening form. Eligible couples were sent massage trough WhatsApp and telegram with study information, consent forms, which allowed them to provide 


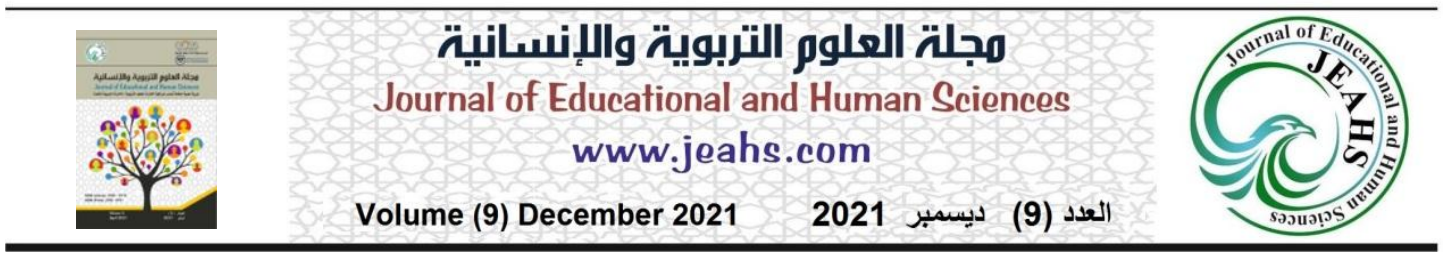

essential information about their marriage and sociodemographic data.

\section{Sample}

The research sample consisted of 112 couples. couples had been married a mean of 9.25 years $(\mathrm{SD}=7.15)$ and had a mean of 3.85 children $(\mathrm{SD}=1.15)$. the average age of their children was 8.52 years $(\mathrm{SD}=5.91)$. employed fulltime $(32 \%$ of wives and $68.5 \%$ of husbands), And have at least a diploma degree (57.7\% of husbands and $42 \%$ of wives).

\section{Measures}

\section{Marital conflict}

Marital conflict was examined through 20 items that show the agreement or disagreement of couples in different areas (e.g. 'children, money, sex). Seven items were from the Beier-Sternberg Discord Questionnaire (Beier \& Sternberg, 1977), six were from the Dyadic Adjustment Scale (Spanier, 1978), and seven more questions were designed to cover potentially conflicting areas. (e.g., recreation, disciplining children). Response options ranged from 1 (Almost always agree) to 5 (Almost always disagree). Composite scores were generated by averaging scores across the items, yielding acceptable internal consistent reliability $(\alpha>.81$ for husbands and wives). In order to have a holistic view, we decided to use different sections of the questionnaires. A higher score on this scale indicates a higher level of conflict.

Emotion regulation (cognitive reappraisal and expressive suppression)

Emotion regulation was measured through an emotion regulation questionnaire (Gross \& John, 2003) in which both couples answered 10 questions of the questionnaire. This questionnaire assesses cognitive reappraisal (e.g., "When I want to feel less negative emotion (such as sadness or anger), I change what I'm thinking about") and expressive suppression (e.g., "When I am feeling positive emotions, I am careful not to express them"). Respondents rated the extent to which they agreed with statements, ranging from 1 (strongly disagree) to 7 (strongly agree). Items related to cognitive reappraisal were averaged to generate a composite score $(\alpha>.78$ for wives and husbands). Items related to expressive suppression were averaged to generate a composite score $(\alpha>.85$ for wives and husbands).

\section{Demographic Variables}

Age, spousal differences in ages, education, length of marriage, income, and religiosity are included as predictors in the regression models. Religiosity is measured by two items assessing the presence of couples' religious affiliation and the frequency of them refer to religious centers. Religious affiliation is measured by respondent's self-report of whether they identify with some religious (e.g., Islam: Shia, Sunni, Christianity etc.). A response of "no religious affiliation" was coded as 0 , while select of a religious affiliation was coded as 1 . Frequency of attending religious services is "How often do you attend religious services?" (1= Once or less than once a year to $4=$ Several times a week). 


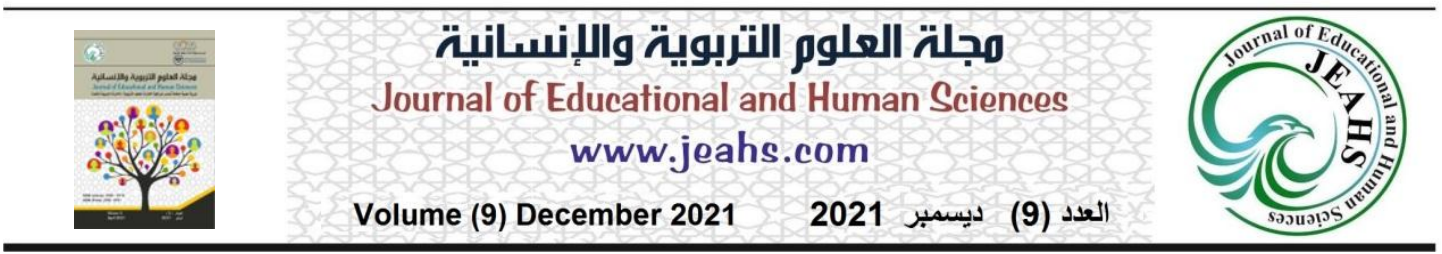

Gender-Related Predictors

According to previous research, gender-dependent variables such as Husbands' Gender Role Attitudes, Wives' Gender Role Attitudes, Husbands' Marital Commitment, Wives' Marital Commitment, Husbands' Marital Equity, Wives' Marital Equity, Husbands' Job Loss, Wives' Job Loss, have played a role in predicting marital conflicts. Therefore, in this research, we include these variables in the research.

\section{Gender role attitudes}

gender role attitudes were assessed with these two questions: "If a man earns a living and the woman takes care of the home and family, it is much better" and "If both husband and wife work full time They do, it's better. They should share household chores evenly." Respondents in these two questions faced a 5-point Likert criterion (1 $=$ strongly agree, $5=$ strongly disagree). The responses of the second case were coded in reverse, so that less scores indicated more "traditional" attitudes and more scores, "more egalitarian" mean scores were obtained.

\section{Commitment}

Marital commitment is measured by the phrase: "Marriage is a lifelong relationship and should never end unless in especial condition." ( $1=$ strongly agree, $5=$ strongly disagree). Gender enters this criterion indirectly because previous research on marital power has focused on commitment as a key variable that indicates relative power in a relationship. In particular, the less commitment a person has to marriage, the more power he or she has due to not investing in the relationship (ie, cost - benefit).

\section{Marital equality}

Marital equality is measured by this phrase: "In a successful marriage, life partners must have the freedom to do whatever they want individually." Answers were strongly agreed $=1$ to strongly disagree $=5$. Responses were coded inversely, with higher numbers indicating lower levels of marital equality.

\section{Employment}

Employment measured by this question "how many hours they worked in the past week and how many hours a week they usually work during the week". Hours of more than 0 , coded 1 , means employment, and 0 means unemployment.

Household transitions

Transitions was coded for the to have children under 18 years old. and the presence of children in the home over 18 years old. In addition, changes in parental status were included in the analysis by including the following: Birth of a new child in a recent year, the launching of childrenn, and move back an adult child to home. 


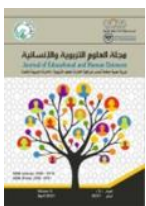

\section{مجلة العلوم التربوية والإنسانية}

Journal of Educational and Human Sciences

www.jeahs.com

Volume (9) December 2021

2021

(9) العدد (9)

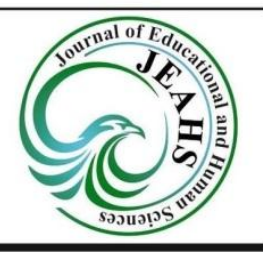

\section{Data Analysis}

The descriptive findings of this study included mean and standard deviation Correlation method was used to determine the predictors of marital conflict. And since one of the aims of this study is to determine the importance of demographic, psychological and ... variables, so the stepwise regression analysis method was used. Stepwise regression analysis allows the researcher to determine the contribution of predictor variables in explaining the variance of the criterion variable. The variable that enters the equation in the first step of the analysis explains the maximum variance of the criterion variable. In this study, we performed two stepwise regression equations for husbands and wives.

\section{Results}

Mean and standard deviation were calculated for each prediction.

Table 1. Descriptive Statistics for Predictor Variables of Marital Conflict

\begin{tabular}{|l|l|l|l|l|}
\hline \multirow{2}{*}{ Variable } & \multicolumn{3}{l|}{ Wives } & Husbands \\
\cline { 2 - 5 } & Mean & Sd & Mean & Sd \\
\hline Demographic predictors & & & & \\
\hline age & 41.2 & 8.5 & 51.2 & 10.5 \\
\hline $\begin{array}{l}\text { Age Difference Between } \\
\text { couples }\end{array}$ & 7.26 & 3.25 & 7.26 & 3.25 \\
\hline Lent of marriage & 14.32 & 5.26 & 14.32 & 5.26 \\
\hline Education & 8.5 & 2.3 & 10.2 & 2.65 \\
\hline Religious Affiliation & 0.97 & 1.02 & 0.91 & 1.89 \\
\hline Religious Attendance & 2.01 & 0.12 & 3.25 & 1.05 \\
\hline $\begin{array}{l}\text { Gender-Related } \\
\text { Predictors }\end{array}$ & & & & \\
\hline Gender Role Attitudes & 7.25 & 1.32 & 8.45 & 1.98 \\
\hline Marital Commitment & 4.15 & 2.58 & 3.25 & 2.35 \\
\hline Marital Equity & 3.58 & 1.25 & 2.36 & 0.14 \\
\hline $\begin{array}{l}\text { Employment time of work } \\
\text { outside of home }\end{array}$ & 6.58 & 2.36 & 2.59 & 1.25 \\
\hline Job Loss & 0.36 & 0.21 & 0.12 & 1.25 \\
\hline Life Transitions & & & & \\
\hline $\begin{array}{l}\text { Children Under 18 in } \\
\text { Home }\end{array}$ & 0.72 & 1.59 & 0.72 & 1.59 \\
\hline Children upper 18 in Home & 0.25 & 2.35 & 0.25 & 2.35 \\
\hline $\begin{array}{l}\text { Child Moves Back into } \\
\text { Home }\end{array}$ & 0.12 & 1.68 & 0.12 & 1.68 \\
\hline Becoming a New Parent & 0.52 & 2.35 & 0.52 & 2.35 \\
\hline launching of childrenn & 0.18 & 1.58 & 0.18 & 1.58 \\
\hline Number of children & 5.2 & 2.36 & 5.2 & 2.36 \\
\hline Psychological factors & & & & \\
\hline
\end{tabular}


هجلة العلوم التربوية والإنسانية

Journal of Educational and Human Sciences

www.jeahs.com

Volume (9) December 2021

2021

(9) العدد (9)

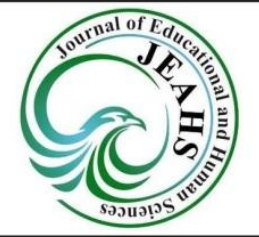

\begin{tabular}{|l|l|l|l|l|}
\hline Marital conflict & 51.25 & 7.26 & 48.26 & 9.26 \\
\hline Emotion regulation & & & & \\
\hline Cognitive reappraisal & 3.52 & 1.75 & 3.32 & 1.25 \\
\hline Expression suppression & 4.21 & 2.51 & 4.91 & 1.85 \\
\hline
\end{tabular}

\section{Predictors of Husbands' Marital conflicts}

Regard to table 2 Correlation coefficients of variables can be seen. Among the demographic variables, Religious Affiliation in women and Religious Attendance in men can predict marital conflict in husbands. regarding gender-related predictors, husbands who reported having more traditional gender roles were generally more conflict. In addition, the more hours husbands worked per week outside the home, the more conflict in their marriages. In The life transitions having children under the age of 18 increase husbands' marital conflicts. In psychological predictors Husbands' higher levels of expression suppression led to increase in husbands' marital conflicts.

Which factor is stronger in predicting marital conflict in husbands?

Husbands's marital conflict regression model predicted $25 \%$ of the variance $(\mathrm{F}=$ $12.36(49.89))$ and is statistically significant. and stepwise method regression shown that Expression suppression as first predictor that inter in model has more power to predict marital conflict in husband $(\mathrm{R} 2=0.108, \mathrm{~F}=39.56 \mathrm{P}<0.0$ ). The next predictions in terms of predictive power are Gender Role Attitudes, Religious Affiliation in wives and Children Under 18 in Home (see table 4).

\section{Predictors of wives' Marital conflicts}

The regression model for wives' marital conflicts predicted $46 \%$ of the variance ( $\mathrm{F}$ $(15.62)=29.98, \mathrm{p}<0.0001)$ and is statistically significant. Among the demographic variables, Religious Affiliation in women can predict marital conflict in wives. Also, Religious Attendance in husbands due to decrease marital conflicts in wives. Believe to marital equity as a gender related predictor increase marital conflicts in wives. Also, time of work outside of home in husbands increase marital conflict in wives. The life transitions of having children under the age of 18 in the home led to increase in marital conflicts, However, the number of children had not correlation to marital conflict as did having an adult child move back into the home. trough of psychological variables Cognitive reappraisal increase was associated with less conflict in women.

\section{Which factor is stronger in predicting marital conflict in wives?}

Wives marital conflict regression model predicts $46 \%$ of the variance $(\mathrm{F}(15.62)=$ $29.98, \mathrm{p}<0.0001)$ and is statistically significant. and stepwise method regression shown that Gender Role Attitudes as first predictor that inter in model has more power to predict marital conflict in wives $(\mathrm{R} 2=0.122, \mathrm{~F}=39.56 \mathrm{P}<0.0)$. The next predictions in terms of predictive power are Religious Affiliation in wives, Cognitive reappraisal, Marital Equity, Children Under 18 in Home (see table 3). 


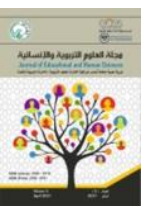

\section{مجلة العلوم التربوية والإنسانية}

Journal of Educational and Human Sciences

www.jeahs.com

Volume (9) December $2021 \quad 2021$

العدد (9)

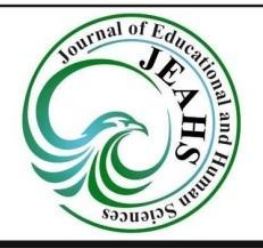

Tbale2. Correlation coefficient of variables

\begin{tabular}{|c|c|c|}
\hline \multirow[t]{2}{*}{ Variable } & \multicolumn{2}{|l|}{ conflicts } \\
\hline & wives & husbands \\
\hline \multicolumn{3}{|l|}{ Demographic predictors } \\
\hline age & 0.025 & 0.068 \\
\hline Age Difference Between couples & 0.058 & 0.065 \\
\hline Education & 0.115 & 0.125 \\
\hline Lent of marriage & $-0.365^{* *}$ & -0.120 \\
\hline Religious Affiliation in wives & -0.015 & $-0.395 * *$ \\
\hline Religious Affiliation in husbands & -0.126 & -0.156 \\
\hline Religious Attendance wives & -0.187 & -0.098 \\
\hline Religious Attendance in husbands & $-0.368 * *$ & $-0.268 *$ \\
\hline \multicolumn{3}{|l|}{ Gender-Related Predictors } \\
\hline Gender Role Attitudes & -0.103 & $0.561 * *$ \\
\hline Marital Commitment & -0.061 & -0.184 \\
\hline Marital Equity & $0.351 * *$ & -0.120 \\
\hline time of work outside of home & $0.268 *$ & $0.215^{*}$ \\
\hline Job Loss & 0.125 & 0.185 \\
\hline \multicolumn{3}{|l|}{ Life Transitions } \\
\hline Children Under 18 in Home & $0.358 * *$ & $0.364 * *$ \\
\hline Child Moves Back into Home & 0.125 & 0.035 \\
\hline Becoming a New Parent & 0.150 & 0.014 \\
\hline launching of childrenn & 0.035 & 0.103 \\
\hline Number of children & 0.068 & 0.026 \\
\hline \multicolumn{3}{|l|}{ Psychological factors } \\
\hline Cognitive reappraisal & $-302 * *$ & $-0.264 *$ \\
\hline Expression suppression & $0.227 *$ & $0.457 * *$ \\
\hline
\end{tabular}

$* \mathrm{p}<.05, * * \mathrm{p}<.01$

Table 3. Multiple regressions for predictors of conflicts in wives (stepwise method)

\begin{tabular}{|c|c|c|c|c|c|c|c|c|c|}
\hline \multirow{2}{*}{$\begin{array}{l}\text { Predictor } \\
\mathrm{s}\end{array}$} & \multirow{2}{*}{$\begin{array}{l}\text { Multiple } \\
\text { regressi } \\
\text { on }\end{array}$} & \multirow{2}{*}{$\begin{array}{l}\text { Coeffici } \\
\text { ent of } \\
\text { determin } \\
\text { ation }\end{array}$} & \multirow{2}{*}{$\begin{array}{l}\text { F ratio P } \\
\text { possibili } \\
\text { ty }\end{array}$} & \multicolumn{5}{|c|}{ Regression coefficient $(\beta),(B)$} & \multirow{2}{*}{$\begin{array}{l}\alpha \\
\text { valu } \\
\mathrm{e}\end{array}$} \\
\hline & & & & 1 & 2 & 3 & 4 & 5 & \\
\hline $\begin{array}{l}\text { Lent of } \\
\text { marriage }\end{array}$ & 0.35 & 0.122 & $\begin{array}{l}\mathrm{F}= \\
52.750 \mathrm{P} \\
<0.0\end{array}$ & $\begin{array}{l}\beta=0.35 \\
t=10.63 \\
p=0.001\end{array}$ & - & - & - & - & $\begin{array}{l}106 . \\
210\end{array}$ \\
\hline
\end{tabular}




\section{مجلة العلوم التربوية والإنسانية}

Journal of Educational and Human Sciences

www.jeahs.com

Volume (9) December $2021 \quad 2021$

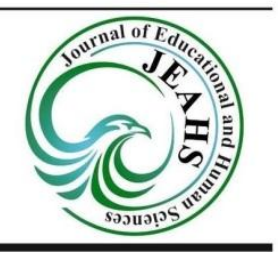

\begin{tabular}{|c|c|c|c|c|c|c|c|c|c|}
\hline $\begin{array}{l}\text { Religious } \\
\text { Attendan } \\
\text { ce in } \\
\text { husbands }\end{array}$ & 0.41 & 0.168 & $\begin{array}{l}\mathrm{F} \quad= \\
32.556 \mathrm{P} \\
<0.0\end{array}$ & $\begin{array}{l}\beta=0.25 \\
\mathrm{t}=8.33 \\
\mathrm{p}=0.001\end{array}$ & $\begin{array}{l}\beta \quad= \\
0.24 \quad \mathrm{t}= \\
8.66 \\
\mathrm{p}=0.00 \\
1\end{array}$ & - & - & - & $\begin{array}{l}71.6 \\
97\end{array}$ \\
\hline $\begin{array}{l}\text { Cognitiv } \\
\mathrm{e} \\
\text { reapprais } \\
\text { al }\end{array}$ & 0.56 & 0.313 & $\begin{array}{l}\mathrm{F} \quad= \\
28.202 \mathrm{P} \\
<0.0\end{array}$ & $\begin{array}{l}\beta=0.22 \\
t=8.01 \\
p=0.001\end{array}$ & $\begin{array}{l}\beta \quad= \\
0.20 \quad \mathrm{t}= \\
7.61 \\
\mathrm{p}=0.00 \\
1\end{array}$ & $\begin{array}{l}\beta=0.18 \\
t=7.31 \\
p=0.001\end{array}$ & - & - & $\begin{array}{l}50.1 \\
56\end{array}$ \\
\hline $\begin{array}{l}\text { Marital } \\
\text { Equity }\end{array}$ & 0.59 & 0.348 & $\begin{array}{ll}\mathrm{F} & = \\
20.02 & \mathrm{P} \\
<0.0 & \end{array}$ & $\begin{array}{l}\beta=0.18 \\
t=7.22 \\
p=0.001\end{array}$ & $\begin{array}{l}\beta \quad= \\
0.17 \quad \mathrm{t}= \\
7.02 \\
\mathrm{p}=0.00 \\
1\end{array}$ & $\begin{array}{l}\beta=0.16 \\
t=6.68 \\
p=0.001\end{array}$ & $\begin{array}{l}\beta=0.16 \\
t=6.51 \\
p=0.001\end{array}$ & - & $\begin{array}{l}44.2 \\
6\end{array}$ \\
\hline $\begin{array}{l}\text { Children } \\
\text { Under } 18 \\
\text { in Home }\end{array}$ & 0.68 & 0.462 & $\begin{array}{ll}\mathrm{F} & = \\
15.62 & \mathrm{P} \\
<0.0 & \end{array}$ & $\begin{array}{l}\beta=0.13 \\
t=4.49 \\
p=0.001\end{array}$ & $\begin{array}{l}\beta \quad= \\
0.12 \mathrm{t}= \\
4.01 \\
\mathrm{p}=0.00 \\
1\end{array}$ & $\begin{array}{l}\beta=0.11 \\
t=3.79 \\
p=0.001\end{array}$ & $\begin{array}{l}\beta=0.10 \\
\mathrm{t}=3.09 \\
\mathrm{p}=0.001\end{array}$ & $\begin{array}{l}\beta \quad= \\
0.10 \mathrm{t}= \\
3.00 \\
\mathrm{p}=0.00 \\
1\end{array}$ & $\begin{array}{l}29.9 \\
8\end{array}$ \\
\hline
\end{tabular}

Table 4. Multiple regressions for predictors of conflicts in husbands (stepwise method)

\begin{tabular}{|c|c|c|c|c|c|c|c|c|}
\hline \multirow{2}{*}{$\begin{array}{l}\text { Predictor } \\
\mathrm{S}\end{array}$} & \multirow{2}{*}{$\begin{array}{l}\text { Multiple } \\
\text { regressi } \\
\text { on }\end{array}$} & \multirow{2}{*}{$\begin{array}{l}\text { Coeffici } \\
\text { ent of } \\
\text { determin } \\
\text { ation }\end{array}$} & \multirow{2}{*}{$\begin{array}{l}\text { F ratio } P \\
\text { possibili } \\
\text { ty }\end{array}$} & \multicolumn{4}{|c|}{ Regression coefficient $(\beta),(B)$} & \multirow{2}{*}{$\begin{array}{l}\alpha \\
\text { valu } \\
\mathrm{e}\end{array}$} \\
\hline & & & & 1 & 2 & 3 & 4 & \\
\hline $\begin{array}{l}\text { Expressio } \\
\mathrm{n} \\
\text { suppressi } \\
\text { on }\end{array}$ & 0.33 & 0.108 & $\begin{array}{ll}\mathrm{F} & = \\
39.56 & \mathrm{P} \\
<0.0 & \end{array}$ & $\begin{array}{l}\beta=0.33 \quad t= \\
15.25 p=0.001\end{array}$ & - & - & - & $\begin{array}{l}75.3 \\
6\end{array}$ \\
\hline $\begin{array}{l}\text { Gender } \\
\text { Role } \\
\text { Attitudes }\end{array}$ & 0.39 & 0.152 & $\begin{array}{l}\mathrm{F}= \\
25.18 \\
\mathrm{P}<0.0\end{array}$ & $\begin{array}{l}\beta=0.28 \quad t= \\
12.52 p=0.001\end{array}$ & $\begin{array}{l}\beta=0.27 \mathrm{t}= \\
11.26 \\
p=0.001\end{array}$ & - & - & $\begin{array}{l}62.3 \\
8\end{array}$ \\
\hline $\begin{array}{l}\text { Religious } \\
\text { Affiliatio } \\
\mathrm{n} \quad \text { in } \\
\text { wives }\end{array}$ & 0.44 & 0.193 & $\begin{array}{l}F \quad= \\
16.89 \\
P<0.0\end{array}$ & $\begin{array}{l}\beta=0.25 \quad t= \\
10.78 p=0.001\end{array}$ & $\begin{array}{l}\beta=0.24 \\
t=9.23 \\
p=0.001\end{array}$ & $\begin{array}{c}\beta=0.19 \\
t=8.52 \\
p=0.001\end{array}$ & - & $\begin{array}{l}52.5 \\
9\end{array}$ \\
\hline $\begin{array}{l}\text { Children } \\
\text { Under } 18 \\
\text { in Home }\end{array}$ & 0.50 & 0.25 & $\begin{array}{ll}\mathrm{F} & = \\
12.36 & \mathrm{P} \\
<0.0 & \end{array}$ & $\begin{array}{l}\beta=0.19 \quad \mathrm{t}= \\
8.12 \mathrm{p}=0.001\end{array}$ & $\begin{array}{l}\beta=0.17 \mathrm{t}= \\
7.63 \\
p=0.001\end{array}$ & $\begin{array}{l}\beta=0.14 \mathrm{t}= \\
6.29 \\
p=0.001\end{array}$ & $\begin{array}{l}\beta=0.16 \\
t=5.26 \\
p=0.001\end{array}$ & $\begin{array}{l}49.8 \\
9\end{array}$ \\
\hline
\end{tabular}




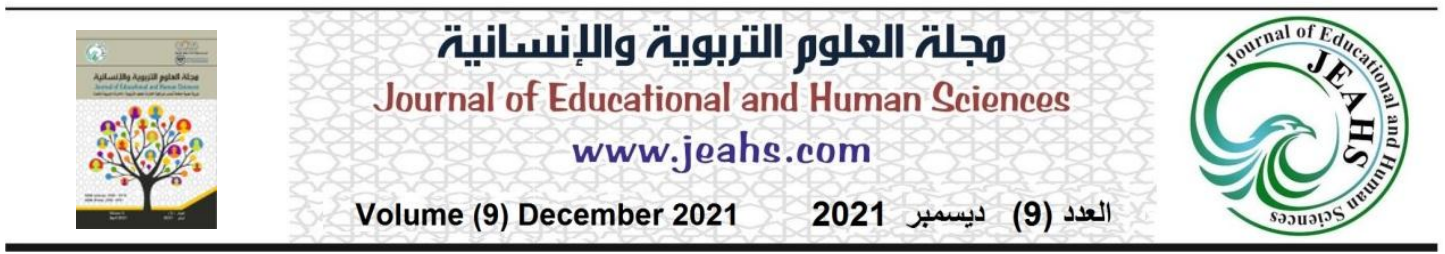

\section{Discussion}

In relation to research questions about what factors can predict marital conflict, the results of the present study show that Expression suppression is most associated with marital conflict in men. The fact that men mostly use es as an emotion regulator leads to the suppression of their feelings and needs in the relationship and as a result leads to more marital conflicts. The results of this study also showed that in husbands, the Gender Role Attitudes causes more marital conflicts in men. Gender Role Attitudes states that "a man should not be emotional" and avoids expressing his feelings. These beliefs also presuppose a man as a strong person in the face of family problems, which in turn leads to an increase in marital conflicts. Religious Affiliation in wives is other predictor that relate to marital conflicts in husbands.

among the demographic variables ... has the most to do with marital conflict. This may be due to the fact that women who identify with a religious structure can have more socializing power than other women, and it can also be due to the fact that their egalitarian expectations are lower From other women.

egalitarian creates a sense of unfairness in wives, especially wives in a traditional country like Iraq, and because the traditional and fanatical structures of society and the family do not allow equality between men and women, this leads to more conflict and a sense of failure among non-religious women. Children Under 18 in Home is another predictor of marital conflict in husbands. Having children under the age of 18 seems to increase parenting responsibilities, and in recent years, with the outbreak of coronavirus and the closure of schools, the task of educating parents has become more burdensome for families and creates more marital conflict.

In wives, the duration of marriage shows a negative relationship with marital conflict in such a way that as time passes from marriage, marital conflict decreases. According to Gottman and Gottman (1999) research, there are two acute periods in married life 0-7 years first and another 16 years more. Most marriages end in divorce over a period of 0-7 years. It seems that the more people in the early years of marriage have less conflict resolution skills, and also these more conflicts can be attributed to the presence of preschool and preschool children, who in the first seven years of marriage are more likely to have children in preschool and elementary school. Having small children and immature conflict resolution skills increase the stress of the couple and may lead to more involvement of the main families. Involvement of the husband or wife's family leads to increased conflicts between couples. Increasing Religious Attendance in husbands leads to reduced conflict. This issue can be considered in the light of the relationship with the presence in religious places and the process of socialization in husbands. Cognitive reappraisal as one of the psychological variables in wives leads to a reduction in marital conflicts. In fact, this factor refers to reforming different situations. Couples may face a variety of conflicts, and Cognitive reappraisal as a review of the situation can help resolve the dispute. Marital Equity is directly related to marital conflicts in women. This is due to the fact that egalitarian beliefs in Iraqi women lead to conflict with their families and husbands. This leads to a sense of injustice towards their sexual role and puts women in conflict with their 


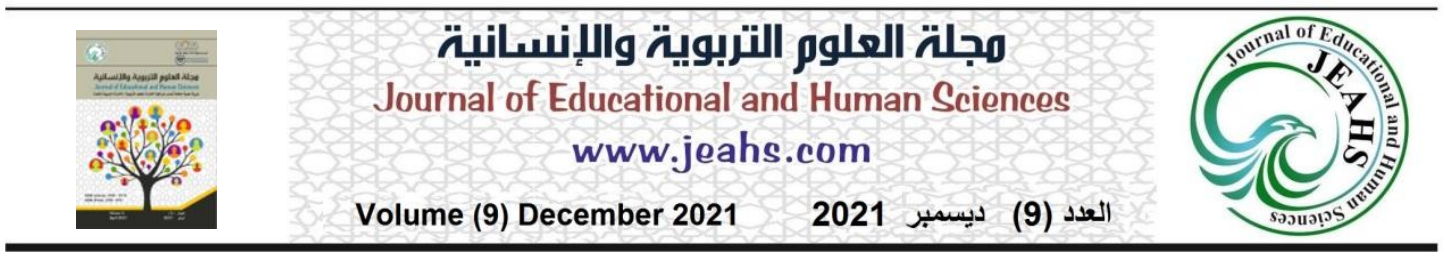

traditional roles and human rights. Having Children Under 18 in Home in women can create many difficulties for women, including increasing the volume of housework and the pressure of raising children. Thus, the existence of children under the age of 18 produces conflict for both spouses.

Multiple stepwise regression showed that marital conflict in husbands is better justified through expression suppression, which is a psychological factor. expression suppression is a factor that leads to the suppression of emotions in men. This factor is very much related to Gender Role Attitudes in husbands. One aspect of sexual role attitudes is the inhibition of emotion in men. Although this reduces conflict in the short term, it increases the intensity of people's reactions to disputed areas in the long term.

\section{Limitation}

As with any correlational studies, it was not possible to control the variables in this study, so investigating the causes of marital conflicts requires experimental research that future research can follow up on this issue. On the other hand, examining marital conflict through a questionnaire may not be the best way to collect data, Guttman points out that it is better to use observational methods to examine marital conflict. It is better to use observational methods to collect data in future research. Another limitation of this study was that the mediating role of psychological variables was not assessed. According to previous research, psychological variables such as emotion regulation can play a mediating role in predicting marital conflict. In future research, it is better to use factor methods to investigate the mediating role of psychological variables.

\section{Reference}

1. Aughinbaugh, A., Robles, O., \& Sun, H. (2013). Marriage and divorce: Patterns by gender, race, and educational attainment. Monthly Lab. Rev., 136, 1.

2. Ben-Naim, S., Hirschberger, G., Ein-Dor, T., \& Mikulincer, M. (2013). An experimental study of emotion regulation during relationship conflict interactions: The moderating role of attachment orientations. Emotion, 13(3), 506.

3. Frye-Cox, N., Ganong, L., Jensen, T., \& Coleman, M. (2021). Marital Conflict and Health: The Moderating Roles of Emotion Regulation and Marriage Order. Journal of Divorce \& Remarriage, 1-25.

4. Frye, N., Ganong, L., Jensen, T., \& Coleman, M. (2020). A dyadic analysis of emotion regulation as a moderator of associations between marital conflict and marital satisfaction among first-married and remarried couples. Journal of Family Issues, 41(12), 2328-2355.

5. Gottman, J. M., \& Gottman, J. S. (1999). The marriage survival kit: A researchbased marital therapy.

6. Gross, J. J. (1998). The emerging field of emotion regulation: An integrative review. Review of general psychology, 2(3), 271-299.

7. Isiozor, N. M., Kunutsor, S. K., Laukkanen, T., Kauhanen, J., \& Laukkanen, J. 


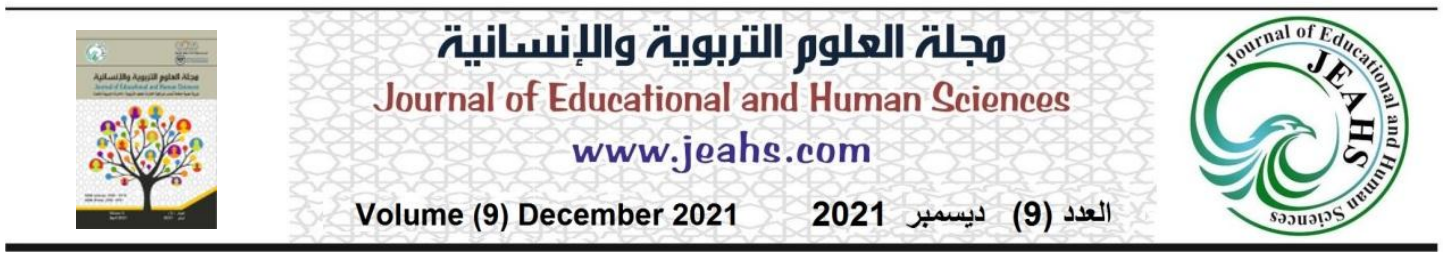

A. (2019). Marriage dissatisfaction and the risk of sudden cardiac death among men. The American journal of cardiology, 123(1), 7-11.

8. John, M. (2017). Causes of marital conflicts in Christian marriages in Domboshava area, Mashonaland east province, Zimbabwe. International Journal of Humanities, Art and Social Studies, 1(2), 59-73.

9. Karakose, T., Yirci, R., \& Papadakis, S. (2021). Exploring the Interrelationship between COVID-19 Phobia, Work-Family Conflict, Family-Work Conflict, and Life Satisfaction among School Administrators for Advancing Sustainable Management. Sustainability, 13(15), 8654.

10. Klein, S. R., Renshaw, K. D., \& Curby, T. W. (2016). Emotion regulation and perceptions of hostile and constructive criticism in romantic relationships. Behavior therapy, 47(2), 143-154.

11. Marphatia, A. A., Ambale, G. S., \& Reid, A. M. (2017). Women's marriage age matters for public health: A review of the broader health and social implications in South Asia. Frontiers in public health, 5, 269.

12. Morris, R. R., Schueller, S. M., \& Picard, R. W. (2015). Efficacy of a webbased, crowdsourced peer-to-peer cognitive reappraisal platform for depression: randomized controlled trial. Journal of medical Internet research, 17(3), e72.

13. Mourtada, R., Schlecht, J., \& DeJong, J. (2017). A qualitative study exploring child marriage practices among Syrian conflict-affected populations in Lebanon. Conflict and health, 11(1), 53-65.

14. Samuel, L. S., \& Alene, G. D. (2021). Effectiveness of Marital Couple Interventions on Marital Conflict: a Systematic Review and Meta-analysis of Experimental Studies.

15. Sheehan, M. M. (2019). 7. Choice of Marriage Partner in the Middle Ages: Development and Mode of Application of a Theory of Marriage. In Marriage, Family, and Law in Medieval Europe (pp. 87-117): University of Toronto Press.

16. Troy, A. S., Shallcross, A. J., \& Mauss, I. B. (2013). A person-by-situation approach to emotion regulation: Cognitive reappraisal can either help or hurt, depending on the context. Psychological science, 24(12), 2505-2514.

17. Visher, E., \& Visher, J. (1997). Stepping together: Creating strong stepfamilies [Leader's manual]. Lincoln, NE: Stepfamily Association of America.

18. Webb, T. L., Miles, E., \& Sheeran, P. (2012). Dealing with feeling: a metaanalysis of the effectiveness of strategies derived from the process model of emotion regulation. Psychological bulletin, 138(4), 775.

19. White, J. M., Martin, T. F., \& Adamsons, K. (2018). Family theories: An introduction: Sage Publications. 